\title{
The relationship between serum uric acid level and concentration of proangiogenic mononuclear progenitor cells in patients with chronic heart failure
}

\author{
Kronik kalp yetmezliği bulunan hastalarda serum ürik asit düzeyi ile proanjiojenik \\ mononükleer projenitör hücre konsantrasyonu arasındaki ilişki
}

Alexander E. Berezin ${ }^{1}$, Alexander A. Kremzer ${ }^{2}$

\begin{abstract}
Objective: Serum uric acid (UA) is considered as a marker of natural progression of chronic heart failure (CHF). Progression of $\mathrm{CHF}$ associates with declining of circulating mononuclear progenitor cells (MPCs) in the blood. The objective of this study was to evaluate the interrelationship between SUA concentrations and proangiogenic MPCs in ischemic CHF patients.

Methods: The study was structured retrospectively after determining the coronary artery disease (CAD) by contrast-enhanced spiral computed tomography angiography in 126 subjects (54 male), aged 48 to 62 years, with CHF. Serum UA level was measured by enzymatic method and $\mathrm{N}$-terminal proBNP (NT-pro-BNP) level was examined by immunoelectrochemiluminesence method. All biomarkers were measured at baseline.
\end{abstract}

Results: Concentrations of SUA were distributed by quartiles (Me; IQR): QI=20.11 (19.06; 22.33) mmol//; QII=27.53 (23.2; 31.10) $\mathrm{mmol} / \mathrm{l}$; QIII=35.80 (32.0; 39.0) $\mathrm{mmol} / \mathrm{l}$; and QIV=44.9 (40.00; 49.60) mmol/l. Cox proportional adjusted Odds Ratios analyses for CD14+CD309+ and CD14+CD309+Tie2+ MPCs by SUA Quartiles (Q) has showed that high $Q(Q 3$ and $Q 4)$ of SUA versus low $Q$ (Q1 and Q2) associated with increased risk of depletion of both CD14+CD309+ and CD14+CD309+Tie2+ MPCs. The ROC analysis has been showed that there was the cut-off point for the SUA level with the best prognostic potential on the risk of decreasing MPCs in both models equal 31.5 $\mathrm{mmol} / \mathrm{l}$.

Conclusion: Circulated level of proangiogenic MPCs is declined progressively depended on quartiles of serum UA level in CHF subjects. We suggest that mild elevation of serum UA might be considered as a predictor of low proangiogenic MPCs in CHF patients. J Clin Exp Invest 2014; 5 (4): $511-520$

Key words: Chronic heart failure, serum uric acid, circulating mononuclear progenitor cells, predictive value
ÖZET

Amaç: Serum ürik asit (ÜA) kronik kap yetmezliğinin (KKY) doğal ilerleyişinin bir belirteci olarak bilinir. KKY ilerlemesi kanda dolaşan mononükleer projenitör hücrelerin (MPH) azalması ile birliktedir. Bu çalışmanın amacı iskemik KKY'li hasatlarda serum ÜA ve proanjiyojenik MPH konsantrasyonları arasındaki ilişkiyi değerlendirmektir.

Yöntemler: Bu çalışma kontrastlı bilgisayarlı tomografi anjiyografisi ile koroner arter hastalığı (KAH) tanısı alan KKY'li 126 hastada (54 erkek)retrospektif olarak yapılmıştır. Serum ÜA enzimatik yöntemle ve N-terminal proBNP (NT-pro-BNP) düzeyi immünoelektrokemilüminesens yöntemi ile çalışıldı.

Bulgular: Serum ÜA konsantrasyonları kuartallar olarak değerlendirildi (Me; IQR): QI=20.11 (19.06; 22.33) $\mathrm{mmol} / \mathrm{l}$; QII=27.53 (23.2; 31.10) mmol/l; QIII=35.80 (32.0; $39.0) \mathrm{mmol} / \mathrm{l}$ ve QIV=44.9 (40.00; 49.60) $\mathrm{mmol} / \mathrm{l}$. Serum ÜA'e göre düzeltilmiş Cox oransal Odds oranı analizleri CD14+CD309+ ve CD14+CD309+Tie2+ MPH için SUA Quartiles (Q) ile yapıldı ve Yüksek serum ÜA Q (Q3 ve $Q 4)$ ve düşük $Q$ (Q1 ve $Q 2)$ 'nin artmış CD14+CD309+ ve CD14+CD309+Tie2+ MPH tükenme riski ile birlikte olduğu gösterildi. ROC analizi ile serum ÜA 31,5 mmol/l değeri MPH azalma riski için en iyi potansiyel cut-off değeri olarak belirlendi.

Sonuç: Konjestif kalp yetmezliği bulunan hastalarda dolaşan proanjiyojenik MPH, serum ÜA kuartallarına bağlı olarak ilerleyici bir şekilde azaldı. Serum ÜA'de hafif artışın düşük proanjiyojenik MPH'nin bir öngördürücüsü olarak kabul edilebilir.

Anahtar kelimeler: Kronik kalp yetmezliği, serum ürik asit, dolaşan mononükleer projenitör hücreler, prediktif değer

${ }^{1}$ State Medical University, Internal Medicine Department, Zaporozhye, Ukraine

${ }^{2}$ State Medical University, Clinical Pharmacology Department, Zaporozhye, Ukraine

Correspondence: Alexander E. Berezin,

Cardiology Unit, Internal Medicine Department, State Medical University, 26, Mayakovsky av., Zaporozhye, Postcode, Ukraine.

Email: dr_berezin@mail.ru

Received: 15.04.2014, Accepted: 24.12.2014

Copyright @ JCEI / Journal of Clinical and Experimental Investigations 2014, All rights reserved 


\section{INTRODUCTION}

Chronic heart failure (CHF) has been remained a potential fatal complication of any cardiovascular diseases and it is characterized by a systemic inflammatory response that leads to end organ damage [1]. Serum uric acid (SUA) has been shown to be an independent predictor of outcome in the general population and in patients with $\mathrm{CHF}$, the metabolic syndrome, type 2 diabetes mellitus (T2DM), and atherosclerosis, chronic kidney disease $[2,3]$. Although sustained hyperuricaemia is considered as independent adverse factor in CHF-related mortality [4], a causal role of SUA is not yet to be established [5]. It has been suggested that there is a relationship between SUA as a "phenotypical" marker of metabolic disorders and a tenderness of reparative processes affected vascular wall and contributed endothelial function. However, less is known about the association between SUA level and circulating mononuclear progenitor cells (MPCs), which have an effect on angiogenesis and tissue reparation [6]. Currently it is well established that MPCs might be recruited resulting in proinflammatory cytokines production that are suitable for CHF $[7,8]$. Substantially, many studies have demonstrated that level of MPCs is declined progressively in the peripheral circulation with increasing severity of symptomatic CHF [9-11]. However, we have been postulated that depletion numerous and functional disability of MPCs in circulation may link SUA with inflammatory response and outcomes in CHF. Therefore, CD34+ MPC populations are not related to cardiovascular remodeling or clinical outcome in CHF patients [11,12]. Recent evidence suggests circulating proangiogenic CD14+CD309+ and CD14+CD309+Tie2+ MPCs levels are decreased in patients with stable CHF [13], but an association of MPCs level with SUA irrespective to clinically significant hyperuricemia is still not investigated.

The objective of this study was to evaluate a relationship between serum uric acid level and circulating proangiogenic MPCs in patients with ischemic mild-to-severe CHF.

\section{METHODS}

\section{Study population}

The study population was structured retrospectively after determining the coronary artery disease (CAD) by contrast-enhanced spiral computed tomography angiography in 126 subjects with symptomatic ischemic mild-to-severe CHF. Chronic heart failure (CHF) was diagnosed according to current clinical guidelines [14]. All patients were Caucasians, have given their written informed consent for participation in the study and met the following inclusion criteria: Q-wave and non-Q-wave MI within 3 months prior to study enrolment; severe kidney and liver diseases that may affect clinical outcomes; malignancy; creatinin plasma level above $440 \mu \mathrm{mol} / \mathrm{L}$; estimated glomerular filtration rate (GFR) $<35 \mathrm{ml} /$ $\mathrm{min} / \mathrm{M}^{2}$; brain injury within 3 months prior to study enrolment; pulmonary edema; tachyarrhythmia; valvular heart disease; thyrotoxicosis; ischemic stroke; intracranial hemorrhage; acute infections; surgery; trauma; all the ischemic events within 3 previous months; inflammations within a previous month; neoplasm; pregnancy; implanted pacemaker, any disorder that, according to investigators, might discontinue patient's participation in the study; and patient's refusal to participate in the study or to give his consent for it.

The study was approved by an institutional review committee. The investigators followed strictly all the requirements to clinical trials in conformity with the World Medical Association Declaration of Helsinki, 1964, Good Clinical Practice provided by International Conference on Harmonization (GCP-ICH), Council of Europe Convention for the Protection of. Human Rights and Dignity of the Human Being in view of using achievements in biology and medicine, Convention on Human Rights and Biomedicine, including Additional Protocol to the Convention on Human Rights and Biomedicine, concerning Biomedical Research, and legislation of Ukraine.

\section{Methods for visualization of coronary arteries}

Multispiral computed tomography angiography $(n=74)$ and/or angiographic study $(n=52)$ have been carried out to verify the ischemic origin of $\mathrm{CHF}$ and have been performed for all patients prior to their inclusion in the study. When atherosclerotic lesions of the coronary arteries were verified, patients were subjected to conventional angiographic examination provided indications for revascularization were available. CAD was considered to be diagnosed upon availability of previous angiographic examinations carried out not later than 6 months ago provided no new cardiovascular events occurred for this period, and the procedure are available for assay. The coronary artery wall structure was measured by means of contrast spiral computed tomography angiography [15] on Somatom Volum Zoom scanner (Siemens, Erlangen, Germany) with two detector rows when holding patient's breathe at the end of 
breathing in. After preliminary native scanning, nonionic contrast Omnipak (Amersham Health, Ireland) was administered for the optimal image of the coronary arteries. To reconstruct the image, 0.6- $\mathrm{mm}$ width axial tomographic slices were used.

\section{Echocardiography examination}

Transthoracic ultrasonic echocardiography was performed according to a conventional procedure on ACUSON apparatus, SIEMENS, Germany, in B-mode regimen and tissue Doppler echocardiography regimen from parasternal, subcostal, and apical positions over the short and long axis with probe $\mathrm{P}$ of $5 \mathrm{MHz}$. Left ventricular end-diastolic and endsystolic volumes were measured by modified Simpson's planimetric method. Left ventricular ejection fraction (LVEF) was assessed in compliance with the requirements of American Society of Echocardiography [16]. Tissue Doppler echocardiography was carried out in 4-, 3- and 2-chamber projections in each of 16 segments of the left ventricle and in 4 spots of the mitral annulus: at the base of posterior septal, lateral, inferior, and anterior left ventricular walls [17].

\section{Calculation of glomerular filtration rate}

Calculation of glomerular filtration rate (GFR) was carried out using MDRD-6 formula [18].

\section{Blood sampling and biomarker measurements}

Venous blood samples were drawn in the fasting state in the morning (at 7-8 a.m.) at baseline into cooled silicone test tubes to detect serum uric acid, N-terminal pro-brain natriuretic peptide (NTpro-BNP), total cholesterol and cholesterol fractions, any biochemical parameters. Samples were processed according to the recommendations of the manufacturer of the analytical technique used. They were centrifuged upon permanent cooling at $6,000 \mathrm{rpm}$ for 3 minutes. Then, plasma was refrigerated immediately to be stored at a temperature not higher than $-35^{\circ} \mathrm{C}$.

\section{Serum uric acid level measurement}

Serum uric acid level was measured by enzymatic methods using chemical analyzer Beckman Synchron LX20. Analytical Range average for serum uric acid was 0.5-82 $\mathrm{mmol} / \mathrm{L}$.

\section{NT-pro-Brain Natriuretic Peptide level measurement}

NT-pro-BNP level was measured by immunoelectrochemiluminesence method using sets by R\&D
Systems (USA) on Elecsys 1010 analyzer (Roche, Mannheim, Germany). Calibration of the assay was performed according to the manufacturer's recommendations and values were normalized to a standard curve.

\section{Cholesterol level measurement}

Concentrations of total cholesterol (TC) and high density lipoprotein (HDL) cholesterol were determined with Dimension Clinical Chemistry System (Dade Behring Inc, Newark, NJ). Low density lipoprotein (LDL) cholesterol was calculated using Friedewald formula [19].

\section{Circulating EPCs}

The flow cytometric technique (FCT) was used for predictable distinguish circulating cells subsets, which depend on expression of CD45, CD34, CD14, Tie-2, and VEGFR2, using High-Definition Fluorescence Activated Cell Sorter (HD-FACS) methodology [20]. Accordingly, the cells in question were phenotyped on the basis of their forward scatter characteristic (FSC) and side scatter characteristic (SSC) profiles. The cells were directly stained and analyzed for the phenotypic expression of surface proteins using anti-human monoclonal antibodies, including anti-CD45 FITS (BD Biosciences, USA), anti-CD34 FITS (BD Biosciences, USA), anti-VEGFR-2 known as anti-CD309 (BD Biosciences, USA), anti-Tie2 (BD Biosciences, USA) and anti-CD14 (BD Biosciences, USA). The fluorescence minus one technique was used to provide negative controls and establish positive stain boundaries. After lysis of erythrocytes with UTILIZE wash solution, the samples were centrifuged at $200 \mathrm{~g}$ for $15 \mathrm{~min}$; then they were washed twice with PBS and fixed immediately.

Double- or triple-positive events were determined using Boolean principles ('and', 'not', 'or', etc.). Circulating EPCs are defined as CD34 / VEGFR2 positive cells in lack of CD45 expression. 500,000 events were analyzed from each tube. For CD14+ populations, coexpression with Tie-2- and/ or VEGFR-2- was determined using quadrant analysis. Standardized cell counts were presented as a percentage of total white blood cells count, which were identified as the total number of all CD45+ cells.

\section{Statistical analysis}

Statistical analysis of the results obtained was carried out in SPSS system for Windows, Version 20 
(SPSS Inc, Chicago, IL, USA). The data were presented as mean $(M)$ and error of mean $( \pm m)$ or $95 \%$ confidence interval ( $\mathrm{Cl}$ ); median $(\mathrm{Me})$ and interquartile range (IQR). To compare categorical variables between groups, Chi2 test (X2) and Fisher $F$ exact test were used. The circulating NT-pro-BNP and SUA level in the blood failed to have a normal distribution, while distribution of the total cholesterol and cholesterol fractions had a normal character (estimated by means of Kolmogorov-Smirnov test) and was not subjected to any mathematical transformation. Concentrations of SUA were distributed by quartiles (Me; IQR): QI=20.11 (19.06; 22.33) $\mathrm{mmol} / \mathrm{L} ; \mathrm{QII}=27.53(23.2 ; 31.10) \mathrm{mmol} / \mathrm{L} ; \mathrm{QIII}=35.80$ (32.0; 39.0) $\mathrm{mmol} / \mathrm{L}$; and QIV=44.9 (40.00; 49.60) $\mathrm{mmol} / \mathrm{L}$. Kruskal-Wallis test was used for difference in medians across quartiles of SUA. One -Way ANOVA with Post Hoc analysis was made for multiple comparisons of variables depending quartiles of SUA. The factors, which could be associated potentially with MPCs declining, were determined by univariate and then multivariate regression analysis. Cox proportional multivariate Odds Ratio (OR) and $95 \% \mathrm{Cl}$ were calculated for all independent predictors of MPCs declining. Receiver operating characteristic (ROC) curves were configured to establish cut-off points of SUA level that optimally predicted decreased MPCs. A calculated difference of $\mathrm{P}<0.05$ was considered significant.

\section{RESULTS}

\section{General characteristics of study patient population}

Table 1 shows a general characteristic of the patients included in the study. As one can see from Table 1, no substantial age and gender differences were found among persons involved in the study. Patients with CHF were distributed in NYHA class I, II, and III (30.2\%; 38.1\%; and $31.7 \%$ respectively), and they, however, had hyperlipidemia (44.4\%), arterial hypertension (66.7\%), T2DM (36.5\%). Multiple Comparisons of variables depending quartiles of SUA were done with One -Way ANOVA with Post Hoc. Because the group sizes were unequal, the harmonic mean of the group sizes was used. Excepted eGFR value and creatinine level patients with different quartiles of SUA were similar in NYHA classes; proportion of comorbidities incidences; body mass index; hemodynamic performances; fasting glucose; HbA1c; NT-pro-BNP, lipids level. Compared with SUA quartiles I-III, patients with QIV SUA level had higher rate of premature CAD in family anamnesis $(P<0.05)$.
Baseline angiographic and treatment characteristics of patients with CHF are presented in Table 2. Coronary arteries with plaques were determined in $36.5 \%$; $33.3 \%$; and $20.2 \%$ for 1 vessel, 2 vessels, 3 and more vessels respectively. All the CHF patients were informed about coronary angiography, and they were treated according to current clinical guidelines with diet, lifestyle modification, and drug therapy that included ACE inhibitors / ARBs, betablockers, mineralocorticoid antagonists, aspirin or other antiagregants, ivabradin, diuretics, as well as statins and metformin if needed. No significant difference between patients related to coronary arteries with plaques determined depending SUA quartiles were found. ACEI/ARBs and aspirin were given for all patients across SUA quartiles in similar proportions. Compared with QI SUA cohort, patients with QII-IV SUA cohorts had a higher prescribing rate of beta-blockers, mineralocorticoid antagonists diuretics $(P<0.05)$, but lower prescribing rate of $i / f$ channel blocker ivabradin, statins $(P<0.05)$.

\section{Determination of serum uric acid level in the study patient population}

For all CHF subjects, the median level of SUA was $31.00 \mathrm{mmol} / \mathrm{L}(95 \% \mathrm{Cl}=22.76-41.89 \mathrm{mmol} / \mathrm{L})$. SUA level was categorized into quartiles (Me; $95 \% \mathrm{Cl}$ ) based upon their distribution among all patients. No significant difference in SUA between women and men with $\mathrm{CHF}(\mathrm{Me}=26.40 \mathrm{mmol} / \mathrm{L} ; 95 \% \mathrm{Cl}=$ 23.51-38.70 $\mathrm{mmol} / \mathrm{L}$ and $\mathrm{Me}=28.70 \mathrm{mmol} / \mathrm{L} ; 95 \%$ $\mathrm{Cl}=24.31-39.20 \mathrm{mmol} / \mathrm{L} ; \mathrm{P}=0.46$ respectively) was found.

\section{Circulating MPCs level in the study patient population}

Table 3 shows the incidence of various phenotypes of circulating CD34+ MPCs. There was a significant change in level of circulating MPCs depended on quartiles of SUA. Subjects with higher SUA quartile had significantly lower MPCs counts when compared with patient with low quartiles.

The authors have found a closely positive association between CD45+CD34+ MPCs count and the LVEF ( $r=0.686 ; P=0.001)$, and a negative association with eGFR ( $r=-0.561 ; P=0.025)$, SUA $(r=-0.482 ; P=0.001)$, and the NT-pro-BNP level $(r=-$ $0.353 ; \mathrm{P}=0.001)$. Circulating CD45-CD34+ MPCs count was associated as a negative linear regression with T2DM ( $r=-0.614 ; P=0.001)$, SUA $(r=-$ $0.466 ; P=0.001)$, hypertension $(r=-0,240 ; P=0,026)$, the NT-pro-BNP level $(r=-0.605 ; P=0.002)$, eGFR 
$(r=-0.423 ; P=0.012)$, adherence to smoking ( $r=-$ $0.222 ; \mathrm{P}=0.040$ ). A positive association was found between the CD45-CD34+ MPCs count and LVEF $(r=0.723 ; P=0.001)$. The CD14+CD309+ subpopulation count was associated positively with LVEF $(r=0.785 ; P=0.001)$, and it was associated negatively with the NYHA class $(r=-0.622 ; P=0.001)$, T2DM $(r=-0.521 ; P=0.001)$, SUA $(r=-0.508 ; P=0.001)$. The
CD14+CD309+Tie2+ subpopulation count showed a positive association with LVEF ( $r=0.639 ; P=0.001)$, eGFR ( $r=0.486 ; P=0.002)$; and a negative association with the NYHA class $(r=-0.657 ; P=0.001)$, SUA $(r=-0.628 ; P=0.001)$, T2DM ( $r=-0.610 ; P=0.001)$, the NT-pro-BNP level $(r=-0.373 ; P=0.001)$, a lowdensity lipoprotein cholesterol $(r=-0.354 ; P=0.001)$.

Table 1. General characteristics of study patients

\begin{tabular}{|c|c|c|c|c|c|c|}
\hline & $\begin{array}{l}\text { CHF across all quar- } \\
\text { tiles of SUA }(n=126)\end{array}$ & $\begin{array}{c}\text { Quartile I (19.1-22.3 } \\
\mathrm{mmol} / \mathrm{L})\end{array}$ & $\begin{array}{l}\text { Quartile II (23.2-31.1 } \\
\mathrm{mmol} / \mathrm{L})\end{array}$ & $\begin{array}{l}\text { Quartile III (32.0-39.0 } \\
\mathrm{mmol} / \mathrm{L})\end{array}$ & $\begin{array}{c}\text { Quartile IV (40.0-49.6 } \\
\mathrm{mmol} / \mathrm{L})\end{array}$ & $\mathrm{p}$ \\
\hline Age, years & $58.34 \pm 9.60$ & $57.70 \pm 6.10$ & $57.40 \pm 6.76$ & $60.30 \pm 4.20$ & $62.60 \pm 6.22$ & NS \\
\hline NYHA class I, n (\%) & $38(30.2)$ & $11(29.0)$ & $9(28.1)$ & $8(29.6)$ & $10(34.4)$ & NS \\
\hline NYHA class II, n (\%) & $48(38.1)$ & $14(36.8)$ & $12(37.5)$ & $10(37.0)$ & $12(41.4)$ & NS \\
\hline NYHA class III, n (\%) & $40(31.7)$ & $13(34.2)$ & $11(34.4)$ & $9(33.3)$ & $7(24.1)$ & NS \\
\hline Hypertension, n (\%) & $84(66.7)$ & $25(65.8)$ & $22(68.8)$ & $18(66.7)$ & $19(65.5)$ & NS \\
\hline Hyperlipidemia, n (\%) & $56(44.4)$ & $17(44.7)$ & $15(46.9)$ & $12(44.4)$ & $12(41.3)$ & NS \\
\hline T2DM, n (\%) & $46(36.5)$ & $14(36.8)$ & $12(37.5)$ & $10(37.0)$ & $10(34.5)$ & NS \\
\hline Smoking, n (\%) & $26(20.6)$ & $8(21.0)$ & $6(18.8)$ & $5(18.5)$ & $7(24.1)$ & NS \\
\hline Mean systolic BP, mm Hg & $130.90 \pm 8.41$ & $127.30 \pm 5.98$ & $133.80 \pm 6.12$ & $129.20 \pm 6.34$ & $128.10 \pm 4.93$ & NS \\
\hline Heart rate, beat per min & $70.52 \pm 3.34$ & $68.56 \pm 5.11$ & $70.44 \pm 5.68$ & $71.36 \pm 4.66$ & $70.16 \pm 5.12$ & NS \\
\hline LV EF, \% & $43.80 \pm 0.77$ & $44.10 \pm 0.94$ & $43.50 \pm 0.97$ & $43.60 \pm 0.79$ & $43.10 \pm 0.85$ & NS \\
\hline eGFR, $\mathrm{mL} / \mathrm{min} / \mathrm{m}^{2}$ & $\begin{array}{c}82.3(95 \% \mathrm{Cl}=68.7- \\
102.6)\end{array}$ & $\begin{array}{c}93.5(95 \% \mathrm{Cl}=88.3- \\
100.3)\end{array}$ & $\begin{array}{c}86.1(95 \% \mathrm{Cl}=68.3- \\
104.1)\end{array}$ & $\begin{array}{c}83.5(95 \% \mathrm{Cl}=68.3- \\
112.6)\end{array}$ & $\begin{array}{c}76.2(95 \% \mathrm{Cl}=61.1- \\
98.3)\end{array}$ & $<0.05$ \\
\hline $\mathrm{HbA} 1 \mathrm{c}, \%$ & $6.8(95 \% \mathrm{Cl}=4.1-9.5)$ & $6.8(95 \% \mathrm{Cl}=3.9-8.9)$ & $6.9(95 \% \mathrm{Cl}=3.5-9.6)$ & $6.8(95 \% \mathrm{Cl}=3.7-8.9)$ & $6.9(95 \% \mathrm{Cl}=3.8-9.2)$ & NS \\
\hline Fasting glucose, mg/dL & $\begin{array}{c}94.12(95 \% \mathrm{Cl}=59.73- \\
175.57)\end{array}$ & $\begin{array}{c}92.49(95 \% \\
\mathrm{Cl}=57.92-153.85)\end{array}$ & $\begin{array}{c}95.56(95 \% \mathrm{Cl}=56.11- \\
161.10)\end{array}$ & $\begin{array}{c}94.30(95 \% \\
\mathrm{Cl}=54.30-171.95)\end{array}$ & $\begin{array}{c}93.58(95 \% \mathrm{Cl}=57.92- \\
162.90)\end{array}$ & NS \\
\hline Creatinine, mg/dL & $\begin{array}{c}0.82(95 \% \mathrm{Cl}=0.66- \\
1.05)\end{array}$ & $\begin{array}{c}0.80(95 \% \mathrm{Cl}=0.60- \\
1.11)\end{array}$ & $\begin{array}{c}0.80(95 \% \mathrm{Cl}=0.63- \\
1.22)\end{array}$ & $\begin{array}{c}0.83(95 \% \mathrm{Cl}=0.61- \\
1.24)\end{array}$ & $\begin{array}{c}0.99(95 \% \mathrm{Cl}=0.71- \\
1.52)\end{array}$ & $<0.05$ \\
\hline $\mathrm{TC}, \mathrm{mg} / \mathrm{dL}$ & $\begin{array}{c}197.4(95 \% \mathrm{Cl}= \\
150.9-236.1)\end{array}$ & $\begin{array}{c}193.5(95 \% \mathrm{Cl}= \\
143.2-247.7)\end{array}$ & $\begin{array}{c}197.4(95 \% \mathrm{Cl}= \\
147.1-243.8)\end{array}$ & $\begin{array}{c}193.5(95 \% \mathrm{Cl}= \\
150.9-232.2)\end{array}$ & $\begin{array}{c}193.4(95 \% \mathrm{Cl}= \\
143.2-239.9)\end{array}$ & NS \\
\hline LDL cholesterol, mg/dL & $\begin{array}{c}125.0(95 \% \mathrm{Cl}= \\
120.4-170.3)\end{array}$ & $\begin{array}{c}114.2(95 \% \mathrm{Cl}= \\
109.9-178.0)\end{array}$ & $\begin{array}{c}121.9(95 \% \mathrm{Cl}= \\
112.2-178.0)\end{array}$ & $\begin{array}{c}125.4(95 \% \mathrm{Cl}= \\
116.5-181.9)\end{array}$ & $\begin{array}{c}126.4(95 \% \mathrm{Cl}=115.3- \\
179.6)\end{array}$ & NS \\
\hline NT-pro-BNP, pg/mL & $\begin{array}{c}1533.6(95 \% \mathrm{Cl}= \\
644.5-2560.6)\end{array}$ & $\begin{array}{c}1263.9(95 \% \mathrm{Cl}= \\
688.2-2120.4)\end{array}$ & $\begin{array}{c}1446.2(95 \% \mathrm{Cl}= \\
612.6-2873.5)\end{array}$ & $\begin{array}{c}1590.6(95 \% \mathrm{Cl}= \\
622.4-2710.2)\end{array}$ & $\begin{array}{c}1873.5(95 \% \mathrm{Cl}= \\
711.2-2790.4)\end{array}$ & NS \\
\hline
\end{tabular}

Note: Cl-confidence interval, T2DM-type 2 diabetes mellitus, eGFR-estimated glomerular filtration ratio, TC-total cholesterol, HbA1c-glycated haemoglobin, LDL-low-density cholesterol, HDL-high-density cholesterol, BP-blood pressure, LV EF-left ventricular ejection fraction, U-unit, NS-not significant.

\section{Association between SUA level and biomarkers}

The univariable linear correlation between SUA and CD45+CD34+ MPCs, CD45-CD34+ MPCs, CD14+CD309+ MPCs, CD14+CD309+Tie2+MPCs, NT-pro-BNP concentration, NYHA class, LVEF,
T2DM, eGFR was evaluated. A significant positive relationship was found between SUA level and NYHA class $(r=0.612 ; P=0.001)$; T2DM $(r=0.462$; $P=0.001)$, NT-pro-BNP ( $r=0.612 ; P=0.001)$, diuretics $(r=0.37, P<0.01)$, body mass index $(r=0.34$, $P<0.05)$, hyperlipidemia $(r=0.32, P<0.05)$, age $(r$ 
$=0.30, \mathrm{P}<0.01)$, and inverse association was obtained between SUA level with eGFR $(r=-0.476$; $\mathrm{P}=0.002)$, LVEF ( $\mathrm{r}=-0.42 ; \mathrm{P}=0.001)$, CD45+CD34+ MPCs ( $r=-0.388 ; P=0.001) ; C D 45-C D 34+$ MPCs $(\mathrm{r}=-0.41 ; \quad \mathrm{P}=0.001) ; \quad \mathrm{CD} 14+\mathrm{CD} 309+\mathrm{MPCs}(\mathrm{r}=-$ $0.397 ; \mathrm{P}=0.001) ; \mathrm{CD} 14+\mathrm{CD} 309+\mathrm{Tie} 2+\mathrm{MPCs}$ ( $r=-$ $0.442 ; \mathrm{P}=0.001)$. We did not find a significant as- sociation with the other biomarkers examined. Multivariable linear regression analyses were performed for CD34+ phenotypes of MPCs, adjusted for eGFR, BMI, LVEF, NYHA, diuretics, and T2DM. We found an independent impact of SUA on counts of CD14+CD309+ MPCs $(r=-0.388 ; P=0.001)$ and CD14+CD309+Tie2+ MPCs $(r=-0.414 ; P=0.001)$.

Table 2. Baseline angiographic and treatment characteristics of the patients with CHF depending quartiles of serum uric acid

\begin{tabular}{|c|c|c|c|c|c|c|}
\hline Variables & $\begin{array}{l}\text { Patients with } \\
\text { all quartiles of } \\
\text { SUA }(n=126)\end{array}$ & $\begin{array}{c}\text { Quartile I } \\
(19.06-22.33 \\
\mathrm{mmol} / \mathrm{L})\end{array}$ & $\begin{array}{l}\text { Quartile II (23.2- } \\
31.10 \mathrm{mmol} / \mathrm{L})\end{array}$ & $\begin{array}{c}\text { Quartile III } \\
(32.0-39.0 \\
\mathrm{mmol} / \mathrm{L})\end{array}$ & $\begin{array}{c}\text { Quartile IV } \\
\text { (40.0-9.6 } \\
\mathrm{mmol} / \mathrm{L})\end{array}$ & $\mathrm{p}$ \\
\hline \multicolumn{7}{|c|}{ Coronary arteries with plaques determined } \\
\hline 1 vessel, $\mathrm{n}(\%)$ & $46(36.5)$ & $12(31.6)$ & $13(40.6)$ & $11(40.7)$ & $10(34.5)$ & NS \\
\hline 2 vessels, n (\%) & $42(33.3)$ & $13(34.2)$ & $10(31.3)$ & $9(33.3)$ & $10(34.5)$ & NS \\
\hline 3 vessels and more, $n(\%)$ & $38(30.2)$ & $13(34.2)$ & $9(28.1)$ & $7(25.9)$ & $9(31.0)$ & NS \\
\hline \multicolumn{7}{|l|}{ Medications } \\
\hline ACEI/ARBs, $n(\%)$ & $126(100)$ & $38(100)$ & $32(100)$ & $27(100)$ & $29(100)$ & NS \\
\hline Aspirin, $\mathrm{n}(\%)$ & $98(77.8)$ & $31(81.6)$ & $25(65.8)$ & $22(81.5)$ & $20(69.0)$ & NS \\
\hline Other antiplatelets,n (\%) & $6(4.8)$ & $2(5.2)$ & $1(3.1)$ & $1(3.7)$ & $2(6.9)$ & NS \\
\hline Beta-blockers, n (\%) & $104(82.5)$ & $16(42.1)$ & $32(100)$ & $27(100)$ & $29(100)$ & $<0.05$ \\
\hline Ivabradine, n (\%) & $37(29.4)$ & $22(57.9)$ & $12(37.5)$ & $2(7.4)$ & $1(3.4)$ & $<0.05$ \\
\hline $\begin{array}{l}\text { Mineralocorticoid antago- } \\
\text { nists, } \mathrm{n}(\%)\end{array}$ & $52(41.3)$ & $4(10.5)$ & $19(59.4)$ & $14(51.9)$ & $15(51.7)$ & $<0.05$ \\
\hline Diuretics, n (\%) & $106(84.1)$ & $19(50.0)$ & $25(78.1)$ & $27(100)$ & $29(100)$ & $<0.05$ \\
\hline Statins, n (\%) & $94(74.6)$ & $33(86.8)$ & $28(87.5)$ & $22(81.5)$ & $11(37.9)$ & $<0.05$ \\
\hline Metformin, n (\%) & $41(32.5)$ & $9(23.7)$ & $11(34.3)$ & $12(44.4)$ & $9(31.0)$ & NS \\
\hline
\end{tabular}

$\mathrm{Cl}$ : confidence interval, ACEI: angiotensin-converting enzyme inhibitor, ARBs: angiotensin-2 receptor blockers, NS: not significant

Table 3. Concentrations of MPCs in relation to serum uric acid (SUA) quartiles

\begin{tabular}{|c|c|c|c|c|c|c|}
\hline \multirow[b]{2}{*}{$\begin{array}{l}\text { Cell phenotypes, } \\
\% \text { (median; IQR) }\end{array}$} & \multirow[b]{2}{*}{$\begin{array}{l}\text { CHF patients } \\
\quad(n=126)\end{array}$} & \multicolumn{4}{|c|}{ SUA quartiles (mmol/l) } & \multirow[b]{2}{*}{$\mathrm{p}$} \\
\hline & & $\begin{array}{c}\text { Quartile I } \\
(19.06-22.33 \\
\mathrm{mmol} / \mathrm{L})\end{array}$ & $\begin{array}{c}\text { Quartile II } \\
(23.2-31.10 \\
\mathrm{mmol} / \mathrm{L})\end{array}$ & $\begin{array}{c}\text { Quartile III } \\
\text { (32.0-39.0 } \\
\text { mmol/L) }\end{array}$ & $\begin{array}{c}\text { Quartile IV } \\
(40.00-49.60 \\
\mathrm{mmol} / \mathrm{L})\end{array}$ & \\
\hline 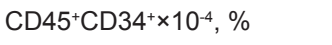 & $1.282(1.21-1.528)$ & $1.77(1.58-1.93)$ & $1.72(1.53-1.91)$ & $1.45(1.21-1.68)$ & $1.05(0.80-1.17)$ & $<0.001$ \\
\hline CD45-CD $34^{+} \times 10^{-4}, \%$ & $0.727(0.54-0.91)$ & $1.01(0.91-1.15)$ & $0.91(0.81-1.01)$ & $0.83(0.72-0.93)$ & $0.63(0.33-0.86)$ & $<0.001$ \\
\hline $\mathrm{CD}_{14}{ }^{+} \mathrm{CD} 309^{+} \times 10^{-4}, \%$ & $29.18(15.0-34.5)$ & $43.9(33.7-54.12)$ & $37.2(28.8-45.6)$ & $28.0(17.5-37.2)$ & $14.0(11.1-19.9)$ & $<0.001$ \\
\hline $\mathrm{CD} 14^{+} \mathrm{CD} 309^{+} \mathrm{Tie}^{2+} \times 10^{-4}, \%$ & $0.67(0.21-1.10)$ & $0.86(0.74-0.98)$ & $0.82(0.73-0.92)$ & $0.67(0.58-0.76)$ & $0.37(0.29-0.56)$ & $<0.001$ \\
\hline
\end{tabular}

Cox proportional adjusted Odds Ratios analyses for CD14+CD309+ and CD14+CD309+Tie2+ MPCs by SUA Quartiles (Q) has showed that high Q (Q3 and Q4) of SUA versus low Q (Q1 and Q2) associated with increased risk of depletion of both CD14+CD309+ and CD14+CD309+Tie2+ MPCs. (Table 4). 
Table 4. Cox proportional adjusted Odds Ratios analyses for CD14+CD309+ and CD14+CD309+Tie2+ MPCs by serum uric acid quartiles

\begin{tabular}{|c|c|c|c|c|c|}
\hline \multirow{2}{*}{ SUA Quartiles } & \multicolumn{2}{|c|}{ SUA, mmol/L } & \multirow{2}{*}{$\begin{array}{l}\text { Odds } \\
\text { Ratio }\end{array}$} & \multirow{2}{*}{$95 \% \mathrm{Cl}$} & \multirow{2}{*}{$\begin{array}{c}p \\
\text { value }\end{array}$} \\
\hline & Mean value & $95 \% \mathrm{Cl}$ & & & \\
\hline \multicolumn{6}{|c|}{ For $\mathrm{CD} 14^{+} \mathrm{CD} 309^{+} \mathrm{MPCs}$} \\
\hline Q1 & 20.11 & $19.06-22.33$ & 1.0 & - & - \\
\hline Q2 & 27.53 & $23.2-31.10$ & 1.02 & $0.88-1.11$ & 0.24 \\
\hline Q3 & 35.80 & $32.0-39.0$ & 1.18 & $1.06-1.29$ & 0.001 \\
\hline Q4 & 44.9 & $40.00-49.60$ & 1.24 & $1.12-1.46$ & 0.002 \\
\hline
\end{tabular}

For $\mathrm{CD}_{14}{ }^{+} \mathrm{CD} 309^{+} \mathrm{Tie}^{+} \mathrm{MPCs}$

\begin{tabular}{llllll} 
Q1 & 20.11 & $19.06-22.33$ & 1.0 & - & - \\
Q2 & 27.53 & $23.2-31.10$ & 1.08 & $1.00-1.20$ & 0.054 \\
Q3 & 35.80 & $32.0-39.0$ & 1.22 & $1.11-1.34$ & 0.001 \\
Q4 & 44.9 & $40.00-49.60$ & 1.38 & $1.20-1.55$ & 0.001 \\
\hline
\end{tabular}

Note: All the respective biomarker-models are adjusted for eGFR, BMI, LVEF, NYHA, diuretics, and T2DM

The predictive value of SUA level with respect to the MPCs with phenotypes CD14+CD309+ and CD14+CD309+Tie2+ in the patients with CHF was performed using ROC-analysis, the results of which are presented in Fig. 1. The findings suggest a high predictive power of SUA in the both models for declining of CD14+CD309+ and CD14+CD309+Tie2+ MPCs in CHF patients. The estimated AUCs (area under curves) were 0.631 (sensitivity $=63.9 \%$; specificity $=56.2 \%$ ) and 0.687 (sensitivity $=72.2 \%$; specificity $=52.9 \%$ ) respectively. In this case, the cut-off point for the SUA level that had the best prognostic potential on the risk of decreasing MPCs in both models was $31.5 \mathrm{mmol} / \mathrm{L}$. Thus, these data suggest that for the CHF patient elevation of SUA might be considered as a predictor of lowed proangiogenic MPCs.

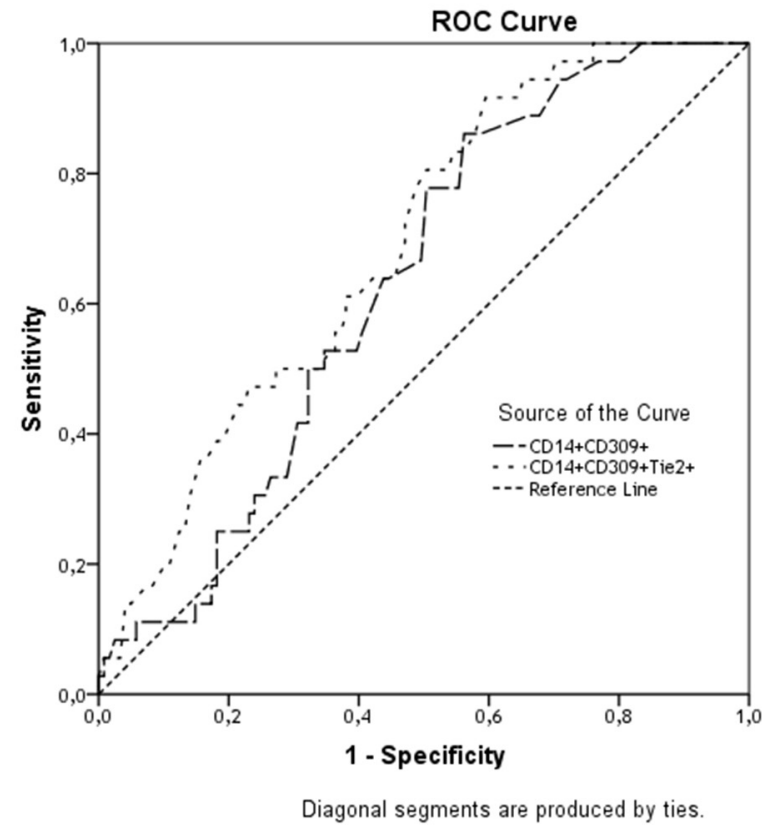

Figure 1. The predictive power of SUA in the both models for declining of CD14+CD309+ and CD14+CD309+Tie2+ MPCs in CHF patients. Results of the Receive Operation Characteristics analysis

Area under the curve

\begin{tabular}{lccccc}
\hline \multirow{2}{*}{ Test Result Variables } & Area & Std. Error & & & \multicolumn{2}{c}{ Asymptotic 95\% Confidence Interval } \\
\cline { 5 - 6 } & & & Asymptotic Sig. ${ }^{b}$ & Lower Bound & Upper Bound \\
\hline CD14 $^{+}$CD309 & & & 0.017 & 0.540 & 0.722 \\
CD14 & 0.631 & 0.047 & 0.001 & 0.598 & 0.776 \\
\hline
\end{tabular}

The test result variables: $\mathrm{CD} 14^{+} \mathrm{CD} 309^{+}, \mathrm{CD} 14^{+} \mathrm{CD} 309^{+} \mathrm{Tie} 2^{+}$has at least one tie between the positive actual state group and the negative actual state group.

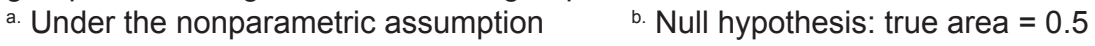

\section{DISCUSSION}

Previously reports have been predominantly elucidated a relationship between cardiovascular outcomes and documented hyperuricemia in patients with acute and chronic heart failure $[3,21,22]$. The effects of SUA on all-cause mortality at different SUA cut-offs in CHF patient population was evaluated using meta-regression. There was a linear association between SUA after $7 \mathrm{mg} / \mathrm{dL}$ and mortality [23]. Arguing against a pure protective role of SUA in cardiovascular disease [24], we found that levels of SUA remained independently associated with lowed proangiogenic MPCs after adjusting for parameters with known impact on concentrations of MPCs. Moreover, even tendency to increase of SUA in CHF patient population associated with pro- 
gressively declining proangiogenic MPCs, which have a tremendous tissue repair capacity. Probably, these findings might be taken into consideration to be explaining controversial role of SUA in CHF evolution and outcomes. Really, significant association between high SUA level and BMI, diuretic use, some biomarkers, such as NT-pro-BNP, as wells as with hemodynamic performances (E/Ea and LVEF) even beyond declining eGFR was frequently noted in recent investigations [23,25]. Amin et al. [26] reported that mild elevated SUA levels in patients with systolic CHF is associated with impaired clinical and hemodynamic profile and might be used as a noninvasive indicator of elevated left ventricular filling pressures. Misra et al. have been evaluated the independent impact of CHF status (compensation or decompensation) on SUA levels among men with high cardiovascular risk profile [27]. Investigators found that mild elevated SUA associated with increased risk of $\mathrm{CHF}$ decompensation $(\mathrm{OR}=1.67$; $95 \% \mathrm{Cl} 1.21$ to 2.32 ).

Although hyperuricemia predominantly affects men, in our study we have not received a confirmation of differences in SUA between men and women with CHF. Noted, that there was not a documented hyperuricemia (SUA $\geq 6 \mathrm{mg} / \mathrm{dL}$ for women and $\geq 8$ $\mathrm{mg} / \mathrm{dL}$ for men) especially required treatment in patients enrolled in the study. However, the interpretation of SUA levels for individual CHF patients may be confusing, but even small increased SUA levels at symptomatic CHF might be discussed as a marker of endothelial dysfunction and, probably, as an indicator of tissue repair disorders. Current evidence suggests that SUA could be a marker of oxidative damage in several settings distinguished $\mathrm{CHF}$, such as overweight, obesity, diuretic use. We confirmed a slight linear association SUA with $\mathrm{BMI}$ and diuretic use, but direct effect of BMI and diuretic use on number of circulating MPCs was not found. It has predisposed that SUA may realize their capacity for modulating tissue damage through other mechanisms irrespective SUA clearance. Therefore, it is not clear whether this increase in SUA levels may be a counter-regulatory process or a pathophysiological detrimental factor. Because SUA is a product of xanthine oxidase (XO), apoptosis and tissue hypoxia that are suitable for $\mathrm{CHF}$ lead to increased purine catabolism, which, in turn, increases XO activity and subsequently SUA levels [28]. Indeed, has a significant association with poor outcomes in CHF patients without CKD but not in those with CKD [28-30], suggesting that hyperuricemia may predict poor outcomes when it is primarily a marker of increased XO activity, but not when it is primarily due to impaired renal excretion of uric acid [29]. In controversy of data presented by Filippatos et al (2011) [28], no association between SUA and BMI was found in our study. Diuretics, widely used to treat CHF, increase SUA by stimulating the reabsorption of sodium and urate in the proximal tubule. Although we obtained an association between SUA and diuretics administration, the direct effect of diuretics in depletion of MPCs in patient study population was not determined. Additionally, increased SUA might also associated with coronary artery disease and with its risk factors, such as obesity, hypertension, hypertriglyceridemia, dyslipidemia and T2DM, and worsen renal function. Multivariable linear regression analyses that was performed for CD34+ phenotypes of MPCs with adjustment for eGFR, LVEF, NYHA, diuretics, and T2DM, has been showed an independent impact of SUA on counts of CD14+CD309+ MPCs and CD14+CD309+Tie2+ MPCs. We suggest that tissue ischemia determines an increase in $\mathrm{XO}$, which leads to an increase in SUA levels, and mediates suppression of recruitment, mobbing, differentiation and functional status of MPCs through Akt / STAT /MAP-kinase mechanisms, that is reflection of chronic inflammatory, oxidative stress and, probably, catabolic state suitable for $\mathrm{CHF}[31,32]$.

\section{Study Restrictions}

This study has some restrictions. The authors believe that a greater cohort is to be desirable to improve the power of the study. There is a variation in the definition of EPCs, the number of existing cardiovascular risk factors in various patients, and in the interaction between EPCs and other hematopoietic progenitor, inflammatory cells or platelets. The authors suppose that these restrictions might have no significant impact on the study data interpretation.

Finally, significant confounder impacting SUA levels on population of proangiogenic MPCs with involving several pathogenetic mechanisms are predisposed. It is possible to address to new investigations whether relationships between SUA and proangiogenic MPCs are multidimensional, or if they can be associated with clinical outcomes.

In conclusion, circulating level of proangiogenic MPCs is declined progressively depended on quartiles of SUA level in CHF subjects. We suggest that mild elevation of SUA (>31.5 mmol / L) might be considered as a predictor of lowed proangiogenic MPCs in CHF patient population. 


\section{Abbreviations}

BMI: Body Mass Index; CAD: Coronary Artery Disease; T2DM: Type two Diabetes Mellitus; eGFR: Estimated glomerular filtration rate; HbA1c: Glycated hemoglobin; CHF: Chronic Heart Failure; LVEF: Left Ventricular Ejection Fraction; SUA: serum uric acid; MPCs-mononuclear progenitor cells; LDL: low-density cholesterol, HDL: high-density cholesterol.

\section{Acknowledgement}

We thank all patients for their participation in the investigation, staff of the Regional Zaporozhye Hospital (Ukraine) and the doctors, nurses, and administrative staff in City hospital \# 6 (Zaporozhye, Ukraine), general practices, and site-managed organizations that assisted with the study.

\section{ETHICAL PRINCIPLES}

The investigators followed strictly all the requirements to clinical trials in conformity with the World Medical Association (WMA) Declaration of Helsinki, 1964, Good Clinical Practice provided by International Conference on Harmonization (GCP-ICH), Council of Europe Convention for the Protection of Human Rights and Dignity of the Human Being in view of using achievements in biology and medicine, Convention on Human Rights and Biomedicine, including Additional Protocol to the Convention on Human Rights and Biomedicine, concerning Biomedical Research, and legislation of Ukraine.

\section{Funding}

This research received no specific grant from any funding agency in the public, commercial, or notfor-profit sectors.

\section{The author contributions}

$A B$ conceptualized and designed the study and carried out the analysis and interpretation of data. AK performed visualization procedures, carried out the biochemical analysis including the determination of proangiogenic MPCs, and participated to the acquisition and analysis of data. All authors read and approved the final manuscript.

\section{REFERENCES}

1. Hartupee J, Mann DL. Positioning of inflammatory biomarkers in the heart failure landscape. J Cardiovasc Transl Res 2013;6:485-492.
2. Gustafsson D, Unwin R. The pathophysiology of hyperuricaemia and its possible relationship to cardiovascular disease, morbidity and mortality. BMC Nephrol 2013;14:164.

3. Huang $H$, Huang $B$, Li $Y$, et al. Uric acid and risk of heart failure: a systematic review and meta-analysis. Eur J Heart Fail. 2013 Aug 9. [Epub ahead of print]

4. Jeemon P, Prabhakaran D. Does uric acid qualify as an independent risk factor for cardiovascular mortality? Clin Sci (Lond) 2013;124:255-257.

5. Kuo CF, See LC, Yu KH, et al. Significance of serum uric acid levels on the risk of all-cause and cardiovascular mortality. Rheumatology (Oxford) 2013;52:127134.

6. Rehman J, Li J, Orschell CM, March KL. Peripheral blood "endothelial progenitor cells" are derived from monocyte/macrophages and secrete angiogenic growth factors. Circulation 2003;107:1164-1169.

7. Schmidt-Lucke C, Roëssig L, Fichtlscherer S, et al. Reduced number of circulating endothelial progenitor cells predicts future cardiovascular events: proof of concept for the clinical importance of endogenous vascular repair. Circulation 2005;111:2981-2987.

8. Hill JM, Zalos G, Halcox JP, et al. Circulating endothelial progenitor cells, vascular function, and cardiovascular risk. N Engl J Med 2003;348: 593-600.

9. Valgimigli M, Rigolin GM, Fucili A, et al. CD34+ and endothelial progenitor cells in patients with various degrees of congestive heart failure. Circulation 2004;110:1209-1212.

10. Kissel CK, Lehmann R, Assmus B, et al. Selective functional exhaustion of hematopoietic progenitor cells in the bone marrow of patients with postinfarction heart failure. J Am Coll Cardiol 2007;49:2341-2349

11. Fadini GP, Maruyama S, Ozaki T, et al. Circulating progenitor cell count for cardiovascular risk stratification: a pooled analysis. PLoS ONE 2010; 5, e11488.

12. Fritzenwanger M, Lorenz $F$, Jung $C$, et al. Differential number of cd34+, cd133+ and cd34+/cd133+ cells in peripheral blood of patients with congestive heart failure. Eur J Med Res 2009;14:113-117.

13. Bakogiannis C, Tousoulis D, Androulakis E, et al. Circulating endothelial progenitor cells as biomarkers for prediction of cardiovascular outcomes. Curr Med Chem 2012;19:2597-2604.

14. McMurray JJV, Adamopoulos S, Anker SD, et al. ESC Guidelines for the diagnosis and treatment of acute and chronic heart failure 2012. Eur Heart J 2012;33:1787-1847

15. Bluemke DA, Achenbach S, Budoff M, et al. Noninvasive coronary artery imaging: magnetic resonance angiography and multidetector computed tomography angiography: a scientific statement from the American Heart Association Committee on Cardiovascular Imaging and Intervention of the Council on Cardiovascular Radiology and Intervention, and the Councils on Clinical Cardiology and Cardiovascular Disease in the Young. Circulation 2008;118:586-606 
16. Schiller NB., Shah PM., Crawford M, et al. Recommendations for quantitation of the left ventricle by two-dimensional echocardiography. American Society of Echocardiography Committee on Standards, Subcommittee on Quantitation of Two-Dimensional Echocardiograms. J Am Soc Echocardiogr 1989;2:358367.

17. Pellerin D., Sharma R., Elliott P., Veyrat C. Tissue Doppler, strain, and strain rate echocardiography for the assessment of left and right systolic ventricular function. Heart 2003;89(90003):iii9-17

18. Levey AS, Stevens LA, Schmid CH, et al. for the CKDEPI (Chronic Kidney Disease Epidemiology Collaboration). A new equation to estimate glomerular filtration rate. Ann Intern Med 2009;150:604-612.

19. Friedewald WT, Levy RI, Fredrickson DS. Estimation of the concentration of low-density lipoprotein cholesterol in plasma, without use of the preparative ultracentrifuge. Clin Chem 1972;18:499-502.

20. Tung JW, Parks DR, Moore WA, et al. New approaches to fluorescence compensation and visualization of FACS data. Clin Immunol 2004;110:277-283.

21. Málek F, Ošt'ádal P, Pařenica J, et al. Uric acid, allopurinol therapy, and mortality in patients with acute heart failure-results of the Acute HEart FAilure Database registry. J Crit Care 2012;27:737.e11-24.

22. Manzano L, Babalis D, Roughton M, et al; SENIORS Investigators. Predictors of clinical outcomes in elderly patients with heart failure. Eur $\mathrm{J}$ Heart Fail 2011;13:528-536.

23. Tamariz L, Harzand A, Palacio A, et al. Uric acid as a predictor of all-cause mortality in heart failure: a metaanalysis. Congest Heart Fail 2011;17:25-30.
24. Alcaíno $H$, Greig $D$, Castro $P$, et al. The role of uric acid in heart failure. Rev Med Chil 2011;139:505-515.

25. Hsieh MC, Su HM, Wang SY, et al. Significant correlation between left ventricular systolic and diastolic dysfunction and decreased glomerular filtration rate. Ren Fail 2011;33:977-982.

26. Amin A, Vakilian F, Maleki M. Serum uric acid levels correlate with filling pressures in systolic heart failure. Congest Heart Fail 2011;17:80-84.

27. Misra D, Zhu Y, Zhang Y, Choi HK. The independent impact of congestive heart failure status and diuretic use on serum uric acid among men with a high cardiovascular risk profile: a prospective longitudinal study. Semin Arthritis Rheum 2011;41:471-476.

28. Filippatos GS, Ahmed MI, Gladden JD, et al. Hyperuricaemia, chronic kidney disease, and outcomes in heart failure: potential mechanistic insights from epidemiological data. Eur Heart J 2011;32:712-720.

29. Wu AH, Ghali JK, Neuberg GW et al. Uric acid level and allopurinol use as risk markers of mortality and morbidity in systolic heart failure. Am Heart J 2010;160:928-933.

30. Kim H, Shin HW, Son J, et al. Uric Acid as prognostic marker in advanced nonischemic dilated cardiomyopathy: comparison with $\mathrm{N}$-terminal pro B-type natriuretic peptide level. Congest Heart Fail 2010;16:153-158.

31. Waring WS, Webb DJ, Maxwell SRJ. Effect of local hyperuricemia on endothelial function in the human forearm vascular bed. $\mathrm{Br} \mathrm{J}$ Clin Pharmacol 2000;49:511-515.

32. Trachtenberg $\mathrm{BH}$, Hare JM. Biomarkers of oxidative stress in heart failure. Heart Fail Clin 2009;5:561-577. 